\title{
The Political Economy of SOE Privatization and Governance Reform in the MENA Region
}

\author{
Ibrahim Akoum \\ College of Business Administration, Rafik Hariri University (RHU), P.O. Box 10 Damour, Chouf 2010, Lebanon \\ Correspondence should be addressed to Ibrahim Akoum, akoumif@rhu.edu.lb
}

Received 23 September 2012; Accepted 10 October 2012

Academic Editors: F. R. Fitzroy, C. A. Gallet, and E. Yeldan

Copyright () 2012 Ibrahim Akoum. This is an open access article distributed under the Creative Commons Attribution License, which permits unrestricted use, distribution, and reproduction in any medium, provided the original work is properly cited.

The purpose of this paper is to shed light on the political economy aspects of state-owned-enterprises (SOEs) governance and privatization in the Middle East and North Africa (MENA) region. In particular, the paper presents an overview of privatization in the region and examines the extent to which SOEs operate at arm's length from the public sector and the motives for this behavior. Showing empirically the region's relative reticence on privatizing public assets, the paper highlights the political economy aspects contributing to this impasse, offers Lebanon as a case study, and suggests a policy framework for successful reform of SOEs. Highlighting the lack of sustainable drives for SOEs reform and privatization in the region and the need for better governance systems based on the rule of law, property rights protection, and combating corruption, the paper proposes policy options to deal with privatization and improve the governance of SOEs through advocating a state-owned enterprise governance framework. This framework suggests subjecting SOEs to regulation and supervision of more than one government entity as opposed to only one ministry of custody. This should help to ensure a level-playing field in the industry and reduce the pressure on SOEs to heed to political pressures.

\section{Introduction}

The Middle East and North Africa is a region of enormous resources that are deemed underutilized and sometimes grossly mismanaged, mainly as a consequence of public sector dominance and poor governance systems. Hence, privatization and state ownership pose controversial issues in the region, and much of this contention is rooted in the political and economic makeup of its regimes. As such, progress in this area, or the lack of it, may be explained by the influences of factors including the "public choice" theory arguments of malevolent public bureaucrats and politicians, partisan politics, corporate governance practices, globalization of trade and finance, and conditionality attached to structural adjustment programs by multilateral development institutions.

Indeed, developments in the region in the past two years, and in particular the so-called Arab Spring, indicate that absent profound progress on reform and no tangible socioeconomic benefits are to be anticipated, thereby engendering disruptive social unrest. The recent violent "outrage revolutions" that have erupted in Tunisia in December 2010 and inundated the Middle East have been a striking evidence of the impossibility to sustain the existing paradigm of state control, long-lasting regimes, inheritance of power, and marginalization of the young generations in the Arab countries. It is hoped that the Arab Spring will be a potent force for positive change to minimize the role of governments as economic agents, which requires establishing a level playing field to prompt state enterprises to practice financial discipline and exhibit adequate disclosure and transparency.

This paper presents an overview of the evolution of public sector ownership in MENA, examines SOEs performance, highlights privatization activity, and discusses the political economy underpinnings of the privatization process in the region. As a case study, the paper examines the political economy aspects of Lebanon's SOEs and privatization. The paper concludes by offering a generic policy framework to improve the governance of SOEs, despite various peculiarities of individual countries in the region. 


\section{MENA and Public Sector Ownership}

Historically, the governments of the MENA countries have been responsible for planning, organizing, and controlling most of the activities of public institutions [1], and in all Arab countries, history, psychology, law, and politics have combined to produce an essentially restricted privatization process [2]. It is no wonder then that this combination of state dominance and socioeconomic factors have shaped the overall economic structures in the region.

Up until the 1950s, much of the region was still under the mandates of colonial powers, with some countries getting their independence only in the 1970s. Having acquired a higher degree of political sovereignty, concerns over economic development took on more exigency. This change was associated by rejecting not only the political patronage of colonialists but also their economic doctrines that were widely perceived as merely the economic face of colonialism. As a consequence, most countries in the region adopted socialist regimes characterized by the call for protectionism, import substitution, and self-sufficiency. As such, a wave of nationalization ensued, bringing back some assets to state ownership.

To defend this change toward adopting socialist policies, it was argued that more government intervention and state ownership of factors of production should end exploitation and rectify the social and economic problems resulting from market failures of the capitalist system. In this context, the natural resources endowment in the region, and in particular in the oil-rich Gulf Cooperation Council (GCC) (The GCC comprises of Saudi Arabia, Kuwait, Oman, Bahrain, Qatar, and the United Arab Emirates.) countries, has played a decisive factor in state ownership. Yet, the hydrocarbon industry has not been the only sector characterized by state dominance. State ownership includes nearly all productive activities involving areas such as the real estate, telecommunication, construction, manufacturing, electricity, transport, agribusiness, education, and health services.

One major sector that has special implications is the financial services sector where state ownership of financial institutions in many countries still poses a hindrance to these economies as state control of the banking system allows politicians to align credit policies with political considerations and facilitate the financing of inefficient SOEs, especially in countries with heavy-handed dominance of financial institutions. Haddad and Pogodda [3] argue that financial markets in MENA tend to be state-dominated and heavily protected from foreign competition, with state ownership as high as 95 percent of total banking assets in Algeria, for instance.

Such a situation signifies the importance of governance in the banking sector, in particular, as it provides the lifeline and source of funds to other sectors. Recognizing these issues, the OECD [4] proposed a set of recommendations aimed at ensuring that state-owned banks deal with other SOEs on arm's length basis, and that the state should establish an ownership policy that includes its objectives of ownership, the state's role, and how it intends to implement the ownership policy.
This convoluted situation in the region hindered private sector development and the legal, judicial, and regulatory frameworks have not evolved enough to promote quicker transfer of economic activity to the private sector and strengthen the role of the public sector as a regulator and facilitator of private business.

On the contrary, the public sector bureaucracy and vested interests have generally favored SOEs and the government has not ensured a level playing field. Sullivan and Nadgrodkiewicz [5] note that the constraints to private sector growth are deeply rooted in the region's corporatist legacy with the state as the most important player rather than an impartial arm's-length regulator. The World Bank [6] attributes the unsatisfactory public sector delivery in MENA countries to poor accountability. Chavanasporn and Ewald [7] summarizes the shortcomings of public sector ownership in general.

\section{SOEs Performance}

The outcome of research on performance of SOEs is not conclusive. While some proffer a discussion on the success of some SOEs in the GCC countries [8], others suggest that the relationship between SOE privatization and financial performance is unclear or claim that SOE privatization is ineffective [1], or at least abhorred [9]. However, many others tout a positive impact of privatizing SOEs [10-14].

The World Bank [6] attributes macroeconomic problems in the MENA region to corruption and poor SOEs management. One typical telling story of rampant corruption and abuse of such enterprises refers to some Iraqi state-owned enterprises that have been bombed and destroyed during the Iran-Iraq war in the 1980s, but their employees have been paid ever since [15]. Graycar and Villa [16] highlights the negative impact of corruption on good government and administrative practice.

Examining privatization in Egypt, Omran [17] found that privatization can be an effective tool in enhancing SOEs financial and operating performance. For his part, Kauffmann and Wegner [18] conclude that privatization in the MENA region has had a positive impact on corporate efficiency and performance in the competitive sector and contributed to government's financing, in particular in terms of subsidy savings to loss making SOEs, and helped foster the development of local capital markets.

From a corporate governance perspective, Wong [19] reveals that in many countries, previous SOE reform efforts failed to deliver sustained improvements in performance because they did not fully address the core governance deficiencies of public enterprise, namely, multiple and conflicting objectives, excessive political interference, and opacity. Omran [20] documents that the higher proportion of outside directors and the change in the board composition following privatization have a positive effect on firm performance and Stiglitz [21] claims that statistical studies suggest that privatization without restructuring and corporate governance does not contribute to economic growth. Likewise, Reddy et al. [22] note the positive effect of corporate governance on firm performances. 


\section{Privatization in MENA}

A confluence of factors has collaborated in pushing the privatization agenda forward in the region, but it was not until the 1980s that the features of the new approach have started to emerge; a manifestation of the recognition that the existing economic paradigm of state ownership has not conferred the benefits claimed for it. It became widely acknowledged that public sector dominance has not promoted economic and social development, and calls increased for a different economic paradigm based on greater role of the private sector and for a smaller public sector bureaucracy.

Despite reluctance at first, countries in the region have begun to implement privatization, with Morocco as the first Arab country to formally endorse privatization as a policy, and was quickly followed by Tunisia, Jordan, and Egypt; it is significant that except for Tunisia, Arab countries which embarked on privatization did so under some degree of pressure from international financial institutions [23]. This pressure intensified in the 1980s as the oil prices dropped sharply and many of the countries resorted to the World Bank and the IMF and were engaged in structural adjustment programs; a main ingredient of which was public sector rehabilitation and privatization. Other reasons for considering privatization included are the need to strengthen economic competitiveness and tackle high poverty incidence [18].

More countries followed the first movers including Lebanon and the six GCC countries. Yet, there had been very little progress to show for till 2005, except for few transactions in Oman and Saudi Arabia, as no privatization activities took place in Kuwait, Bahrain, and the United Arab Emirates [24]. In Libya, after decades of socialist-style economic policy and international isolation, the country began tentative liberalization of some parts of the economy and 110 stateowned companies were privatized since 2000, and officials argued that privatization policy has not been driven by a need for capital but rather to the need for attracting private sector expertise to create jobs and diversify the economy [25].

Overall, the privatization drive has not been stanch enough to make a significant difference in state ownership in the region. Data shows (The source of data is the World Bank privatization database (http://rru.worldbank.org/), which covers data only up to 2008. Only data that generate revenue for the government from privatization or private sector participation in an existing state-owned enterprise (SOE) or other government assets are included. The data give information on the sale price of transactions on an "announcement" basis rather than on the basis of actual flows of receipts, which may be paid for over several years. Data do not include new greenfield investments that did not involve payments to the government, funds committed or invested by new owners, and build-operate-transfer schemes which do not involve payments to the governments.) that total privatization proceeds in the developing countries totaled about $\$ 774$ billion during the period 1988-2008, of which the share of the MENA region amounted to only $\$ 38.4$ billion, representing a mere 5 percent (All data calculations and graphics are prepared by the author based on raw data from the World Bank's online privatization database.). As shown in Figure 1,

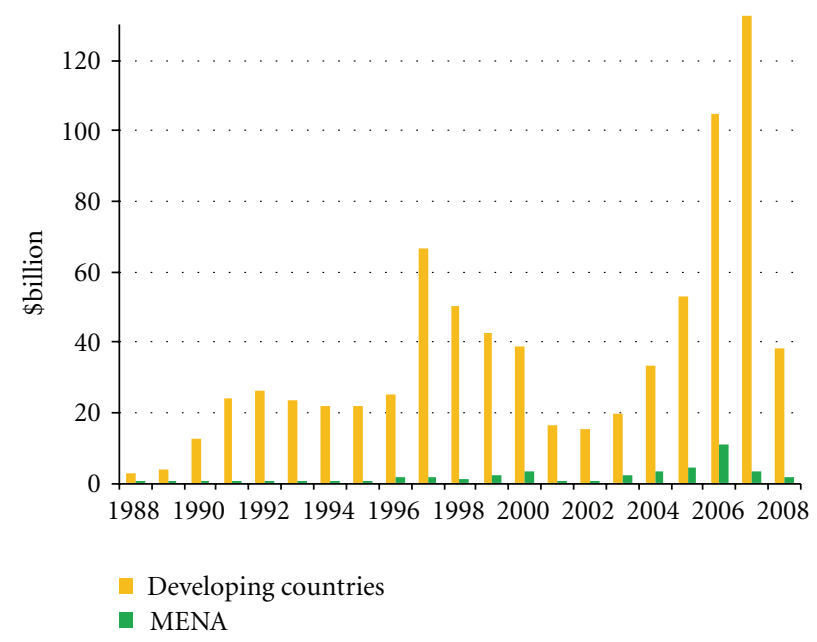

FIgURE 1: Total privatization proceeds.

the share of the MENA region of total privatization proceeds in developing countries has been very modest in the past few years. This level of privatization transactions might be considered relatively reasonable given that the gross domestic product (GDP) of the MENA region represents only about 5.8 percent of the total output of developing countries. However, the relatively high magnitude of public sector ownership in many countries in the region and the concentration of privatization transactions in only three MENA countries indicate an overall low level of privatization in the region.

For instance, as depicted in Figure 2, during the period 1988-2008, the share of total privatization proceeds in Egypt, Morocco, and Tunisia alone amounted to nearly 81 percent of total proceeds of the MENA region. Figure 3 shows the values of privatization proceeds of MENA countries and the lopsidedness towards these three countries. It is noteworthy that except for Oman, no privatization transactions have been reported in the World Bank privatization database for the other GCC countries.

Likewise, during the period 1988-2008, the number of privatization transactions in the MENA region constituted 4 percent of total transactions of developing countries. Figure 4 shows the annual shares of MENA privatization transactions. Further, about 86 percent of the privatization transactions were made in these three countries, of which 41.9 percent of the transactions were in Egypt, 22.5 percent in Tunisia, and 21.8 percent in Morocco.

With regard to the relative size of regional privatization proceeds in the developing countries and the relative sizes of their economies, Figure 5 shows that privatization proceeds in MENA as share of total privatizations proceeds in the developing countries are proportionate with the size of the region's economic output as share of total output of developing countries. Figure 5 also reveals that privatization activity during the same period has been very high in Eastern Europe and Central Asia, relative to the size of its economy in the developing countries. Further, data also shows relatively low privatization activity in Latin America and South Asian 


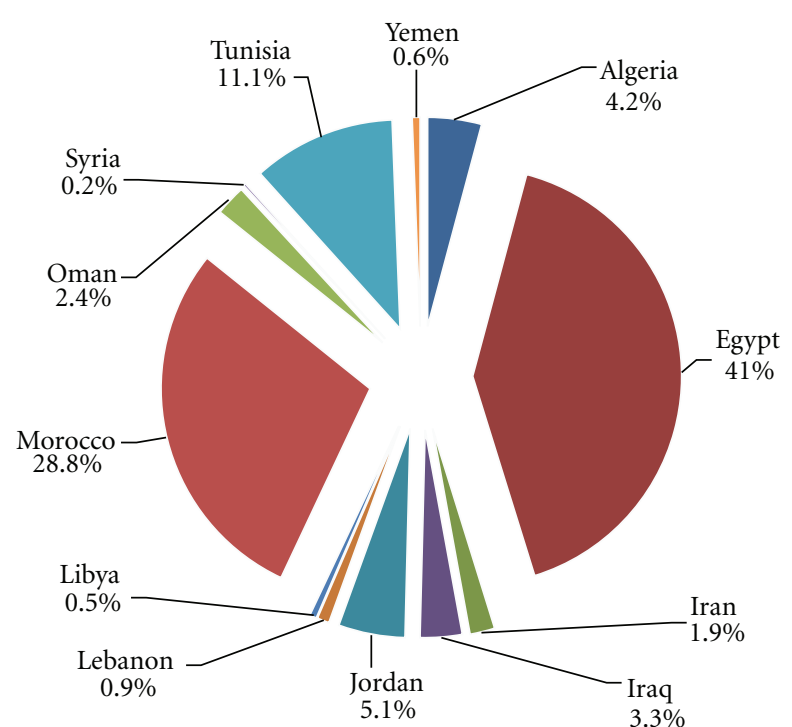

FIGURE 2: Share of MENA privatization proceeds (1988-2008).

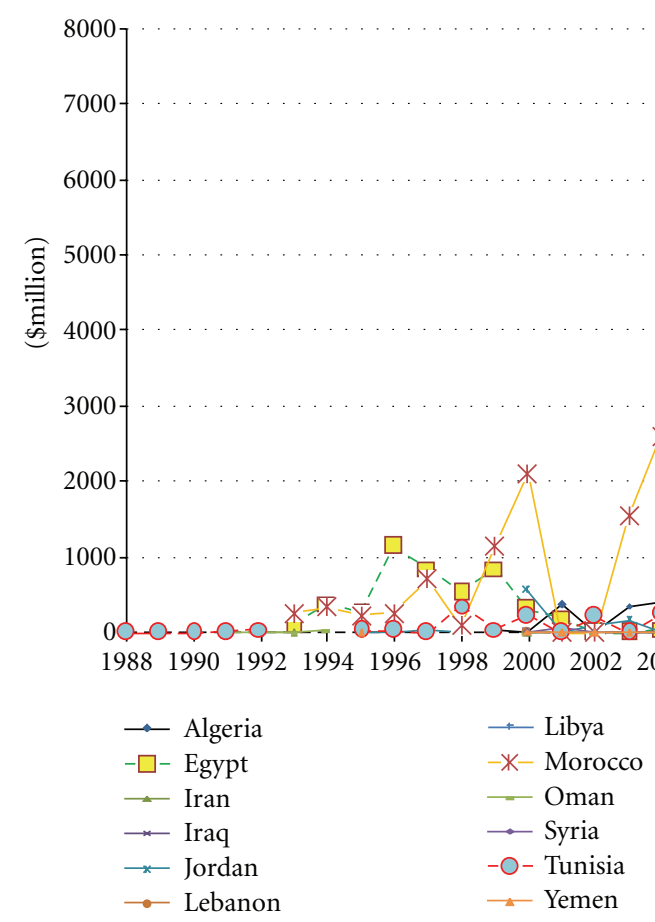

FIGURE 3: Value of privatization proceeds.

countries relative to the size of their economies in developing countries.

With regard to the sectoral composition of privatization transactions in developing countries, the manufacturing and services sector commanded the highest shares amounting to 58 percent of the total value of transactions during the period 1988-2008. As for the MENA region, the infrastructure took the lion's share with 60 percent of transactions, in particular the telecommunications sector, followed by the financial sector with 19 percent.

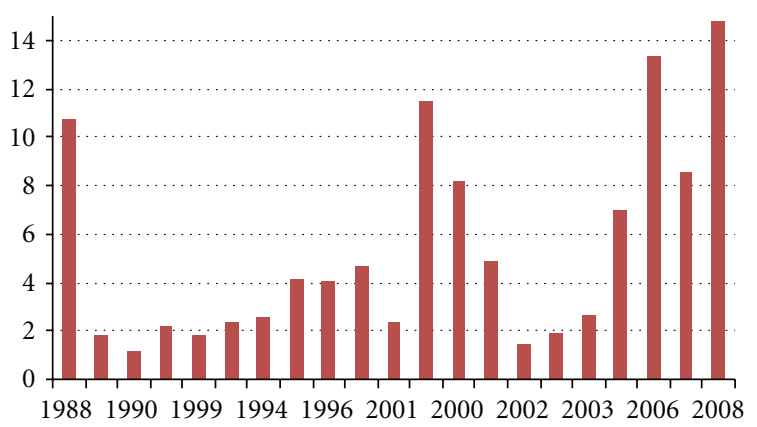

Figure 4: Number of MENA privatization transactions (\% of total developing countries).

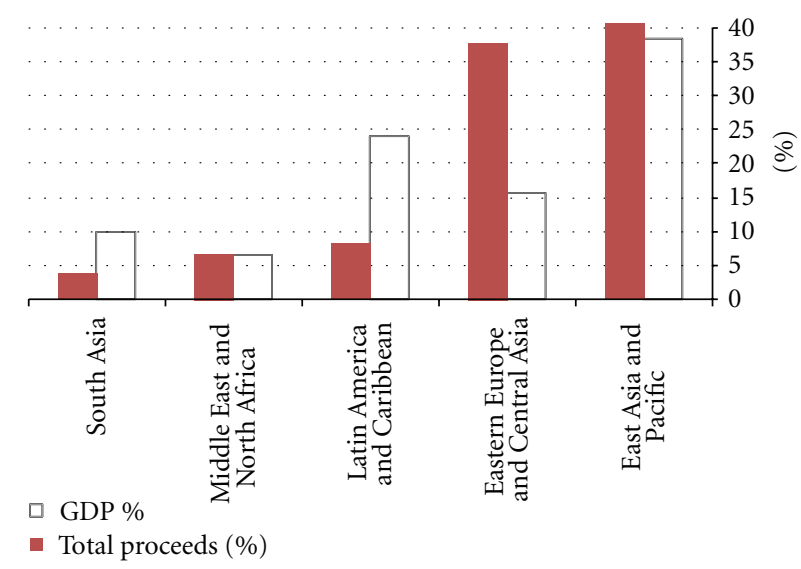

FIGURE 5: Privatization proceeds and GDP by region.

Despite progress, governments' economic role remains large in the region. The private sector accounts on average for less than 50 percent of GDP in the region, while the public sector (including state enterprises) is estimated to account for more than a third of formal employment compared with 18 percent worldwide excluding China [26].

The factors perpetuating this situation are multifold, leading to crowding-out the private sector and to a no level-playing field situation. It is widely known that SOEs in many countries in MENA enjoy preferential treatment including obtaining easy credit from state-owned banks. In some sectors there has been outright prohibition of private sector entrance or other kinds of barriers to entry. It is only relatively recently that private participation has been taking roots in a number of sectors such as the utilities, education, and health services.

\section{The Political Economy of SOEs Privatization}

The World Bank [12] notes that reform entails political costs and that political obstacles are the main reason that SOEs reform has made so little headway throughout the 1980s till the mid-1990s. This argument appears to have been the case in the MENA region. Privatization and state ownership have been controversial subjects in this region for decades and much of the contention is rooted in the political and 
economic makeup and the formation of state ownership of its regimes. As stated earlier, the emergence of independent states in the region during the second half of the twentieth century, with strong nationalistic sentiment, was associated with the feel argument that the state should be the "provider" and engine of social and economic development. In addition, the lack of the appropriate legal and regulatory frameworks for a vibrant and effective private sector has enforced that point of view. But overtime, it was clear that vested interests in the public sector strived to perpetuate their presence and interests at the expense of private sector activity and the interest of society at large.

Public sector reform, including reform of SOEs, has shared the same difficulties confronting the efforts to privatize in much of the region. Entrenched interests of most bureaucrats and many politicians and the fear of losing power and money as a result of changing the status quo have established a potent resistance front to real reform measures.

It is argued that in order to maintain power and further political interest, politicians and bureaucrats use their positions to obstruct, or at least delay, privatizing and reforming SOEs, and SOE managers seek to further their own benefits in the way of more power, larger budgets, and more patronage hiring [27, 28]. Wong [19] and Ficici [29] document numerous cases of disruptive political meddling in SOEs. More recently, Eberhard and Grove [30] note that the likelihood of running down assets to meet short-term political pressures becomes dangerously more likely when state-owned infrastructure companies fall within one sector ministry.

Apart from self-interest, political orientations have significant implications to the way politicians approach privatization and the methods adopted to sell public sector assets. For instance, concluding that the partisan orientation of the government has a significant impact on the methods of privatization, Bortolloti [31] argues that the evidence confirms that privatization is politically motivated, and that a political economy approach is particularly useful in understanding why and how governments privatize. He contends that privatization methods seem to be shaped by political preferences, with market oriented governments involved in spreading share ownership among domestic voters.

Further, Belke [32] refers to the reasoning of partisan theory that right-wing parties favor market solutions in economic policy and have a propensity to sell off state-owned enterprises for electoral incentives as privatization spreads share ownership among domestic voters. Fink [33] presents a similar argument.

Important as they are, political orientation and the "public choice" theory's view of politicians and bureaucrats as malevolent agents immersed in their parochial concerns, have not been the sole factors. Some other important drives include globalization of trade and finance and the influence of multilateral development and financial institutions such as the World Bank and the International Monetary Fund. For example, analyzing the differences in the privatization proceeds raised by European Union and OECD countries during 1990-2000, Obinger and Zohlnhofer [34] asserts that privatizations are part of a process of economic liberalization in previously highly regulated economies, as well as a reaction to the fiscal policy challenges imposed by European integration and the globalization of financial markets.

With regard to international financial institutions' conditionality, Stiglitz [21] asserts that those countries that privatized the fastest got the IMF's seal of approval as the IMF put a host of privatization conditions on its loans to those countries. Echoing this reasoning, Eurodad [35] observes that many countries privatization-related conditions make up a substantial part of their overall conditions from the World Bank and IMF, and that 18 out of the 20 poor countries assessed had privatization-related conditions attached to their development finance from these institutions.

Naturally, despite the common themes mentioned above for privatization, country-specific circumstances also play an essential role in shaping this process. Using a database of 221 privatized firms operating in 27 emerging countries over the 1980-2001 period, Boubakri et al. [10] concludes that privatization is politically shaped and constrained by a dynamic that will differ between countries.

As for MENA countries per se, the World Bank [6] considers that these countries fall short of other countries at similar income levels in the index of quality administration (IQA) in the public sector, causing a governance gap and reducing the incentives of incumbent regimes to strengthen mechanisms of external accountability, and favoring the status quo over reform. Yet, others consider that social and political stability played an important role in the slow pace of privatization in the MENA region as opponents of selling-off public sector assets exerted heavy influence to obstruct it. It is argued, for instance, that fearing social unrest, the Egyptian regime delayed the recommended privatization measures for years before moving with relative vigor to sell off state-owned enterprises in 1993 [36].

As a matter of fact, opposition to privatization has been active and vocal in all MENA countries for varying reasons, and many explanations are presented as culprits in the protraction of the privatization process (see [36-39]).

For his part, Page [40] argues that privatization programs in the region have lacked clear strategic focus, have been implemented on a stop-go basis, and have, in many cases, resulted in the transfer of ownership without an accompanying transfer of state control, and that in a number of Arab countries, fear of labor redundancies has slowed down privatization, particularly in the manufacturing sector. In his opinion, privatization programs have gained and lost momentum because investors have been unsure on governments' intentions with respect to the types of enterprises to be offered for sale, the methods of privatization, and the conditions of sale, including regulations.

Generally speaking, many MENA countries are inhibited by environmental weaknesses in their efforts to privatize, namely, embryonic capital markets, weak private sectors, less than prudent regulations, and acute asymmetries of information [41]. In this regard, the World Bank [6] contends that countries across the MENA region exhibit a pattern of limited and reluctant transparency, which is reflected in the fact that it is the region with the least empirical data on the quality of governance. 


\section{Political Economy of Privatization in Lebanon}

Lebanon presents a conspicuous case of political hindrance to privatization and SOEs reform. Sectarian dominance and its concomitant Muhasasa (Sharing of political as well as public sector and SOEs posts among political and sectarian leaders who nominate their cronies to these posts.) practices in Lebanese politics and public affairs not only consistently delayed the privatization process, but also obstructed public sector rehabilitation programs and SOEs reform in all sectors. Senior and mid-level public sector positions, heads of major municipalities, heads of SOEs, and SOEs board members are distributed among sectarian factions whose leaders name their followers to assume these posts, often irrespective of professional merit. Consequently, these employees are protected by their political and sectarian sponsors and are indeed shielded from accountability. They are practically "untouchables".

Consequently, little has been achieved on the public sector reform front despite the commitments of successive Lebanese governments to international donors to reform and restructure its bloated, inefficient, and ineffective public sector. Lebanon's commitment to privatization has been explicitly stated in various ministerial declarations and pledges made to the international donors who offered financial support to the country under the terms of the three Paris conferences that were held during the period 20012007. But, unfortunately, the intense political bickering and merely paying lip service to real reform by many in the country has severely hampered the process of private sector development and combating public sector inefficiencies and rampant corruption. It appears that SOEs in Lebanon are too-political-to-privatize golden geese and source of political patronage.

State ownership in Lebanon includes a number of sectors, the most controversial of which and the most eligible for privatization are the telecommunications sector, the largest source of revenues after fiscal revenues, and the power sector, a primary source of strain on the government finances. As a matter of fact, these two sectors are the only ones that have privatization laws enacted for them, which is not the case for other sectors such as the public transport and water resources. (see Box 1 for the legal, administrative, and regulatory environments of SOEs in Lebanon).

But even with enacting laws and publicly committing to privatize these two major sectors, actual execution has been moving at an excruciatingly slow pace. In fact, nothing has been done practically beyond the enacting of the privatization laws of these sectors. Shehadi [42], former Head of the Telecommunication Regulatory Authority in Lebanon (TRA), acknowledges that it is taking so long for Lebanon to liberalize the sector because of politics and the resistance of vested interests who have deep connections to the political structure in the country.

As for the power sector, there exists in Lebanon only one company in charge of generation, transmission, and distribution of electricity, that is Electricite Du Liban (EDL), which is widely considered the most inefficient public enterprise in the country, costing the budget nearly 2.2 billion dollars, estimated at a staggering 5.5 percent of the country's output in 2012. Lamenting sectarian opposition to privatization of EDL, despite mismanagement and rampant corruption, Choucair [43] reveals that the company keeps losing money while charging some of the highest rates in the world, and it is a powerful source of political patronage and has long been used by political elites to distribute free electricity and jobs to their constituents. Echoing this claim, Yammine (2010) maintains that businesses and the economy as a whole are suffering from expensive, subpar telecommunication services as Lebanese phone bills remain the highest in the world.

Despite the fact that the telecommunications law adopted in 2002 calls for Ogero, the state-owned fixed line company, to be dissolved into a new company, Liban Telecom, which would be administered separately from the ministry of telecommunications, the vested political and economic interests opposing public sector reform in Lebanon are partly to blame for not pursuing privatization of the telecommunications sector [44].

In fact, opposition to privatization took various forms from vociferous opposition by some politicians and labor unions, to instigating labor protests, impeding, and enacting the needed legal and regulatory structures for privatization. For instance, it is very telling to know that it took five years to agree on the appointment of the board of the Telecommunications Regulatory Authority (TRA).

Accordingly, it can be concluded that Lebanon presents a strikingly disconcerting case of the "public choice" view of politicians and bureaucrats as malevolent agents immersed in their parochial concerns, as opposed to the conventional "public interest" theory where public officials are portrayed as benevolent public servants.

\section{Conclusion and Analysis}

Privatization, governance, corporate governance, and stateowned enterprises (SOEs) represent contentious subjects in the MENA region. The roots of the region's reticence on these issues lie not only in economic and financial factors but also in political and social considerations. The evolution of the region's political and economic structures explains much of its countries' approaches to the overall governance of their economic affairs, and particularly privatization and state ownership of enterprises.

Successful reform requires that they are politically desirable, politically feasible, and that SOEs reform must be credible with no policy reversals [12]. Further, the Bank's findings indicate that more successful reformers made the most of the five components of reforms that are widely recommended, namely, divestiture, competition, hard budgets, financial sector reform, and changes in the institutional relationship between SOEs and government, a notion echoed by more recent research (see [45]).

These requisites for SOEs reform seem to be proven useful in the MENA region and ought to be heeded, since a piecemeal approach to reform has not been able to establish a solid foundation for sustainable social and economic 
There are more than 100 enterprises that can be considered as state-owned enterprises and operate in a wide range of activities including electricity, water, telecommunications, transport, housing, entertainment, media, agriculture, investment promotion, education, and health sectors. These SOEs vary greatly in size and scope and are widely perceived by most Lebanese of all parties and sects as a source of financial drain on the government finances and as entities rampant with corruption and cronyism.

As for the legal, administrative, and regulatory environments, SOEs in Lebanon are established as separate legal entities with legal personality and financial independence. An SOE shall have a board of directors and would be managed by a general manager. However, each SOE lies under the custody of a relevant ministry and the minister serves as the custody minister for the respective SOE. In addition, a number of SOEs are placed under the custody of the presidency of the Council of Ministers.

The Decree no. 4517 enacted in 1972 lays out the provisions governing the formation, operating, and regulating public enterprises in Lebanon.

With regard to the formation of the board of directors, the Decree outlines the personal and professional requirements of all board members, their tenure, duties and responsibilities, and termination of membership. The Decree clearly stipulates that board members and their relatives shall not have a direct or nondirect personal benefit from the operations of the public enterprise. The Decree prohibits board members to serve on more than one public enterprise. It also stipulates that the Chairman of the board and the board members shall monitor the execution of the directives of the board and policies and objectives of the public enterprise.

As for executive management, the Decree also outlines the personal and professional requirements of the general managers of public enterprises, their tenure, duties, and responsibilities. General managers attend the board meeting in an advisory capacity.

With respect to supervisory role, the minister of custody exercises administrative and financial custody authority. The minister of custody appoints a government commissioner who participates in the meetings of the board of directors and provides copies of the minutes of the meetings to the ministry of custody, the Court of Accounts, the central Inspection Board, and the Civil Service Council.

Concerning the regulatory environment, and as implied earlier, the Decree holds that in addition to the ministry of custody, public enterprises come under the regulatory authority of one or more of the following government bodies: the Court of Accounts, the central Inspection Board, and the Civil Service Council.

To strengthen the level of transparency, disclosure, and accountability, the Law no. 326 was enacted in June 2001 to subject SOEs to auditing requirements. Article 73 of the Law stipulates that, in addition to the supervision of the Ministry of Finance and the Court of Accounts, the financial accounts of SOEs enjoying financial and administrative independence shall be subject to internal audit as well as independent external audit. Auditors are appointed jointly by the Minister of Finance and the ministry of custody.

But in practice, due to the need for more adequate laws and regulatory frameworks to organize the work of these SOEs, in addition to the sectarian environment, the relationship between SOEs and their respective custodians has not been very productive.

Lebanon has not enacted privatization laws except for the Telecommunications Sector Law and the Electricity Sectors Law, both enacted in 2002. These laws refer to the Privatization Framework Law of year 2000 which sets up the general privatization framework by regulating its operations and defining its terms and fields of implementation and requires the enactment of a specific law for each sector to be privatized. Although a Telecommunications Regulatory Authority (TRA) has been set up and a decree was issued to appoint its board in 2007, no such authority has been established yet for the electricity sector.

Box 1: SOEs in Lebanon.

development. The uneven progress in the region's economies is a case in point. Kauffmann and Wegner [18] assert that privatization in the region proved to be successful when it was implemented as part and parcel of a more general package of measures aiming at promoting efficiency, private sector development, the improvement of the business climate, and liberalization of the financial market, and when it involved the setting of a regulatory and policy framework. For instance, some country experiences show that privatization can be a catalyst for the development of the private sector if combined with reforms of the business climate and of the financial market [18].

It is true that the MENA region suffers from a number of deficiencies and the lack of a sustainable drive towards reform and private sector development. Despite these challenges and impediments, the region has the potential to attain the needed levels of economic growth provided that MENA's ample human, natural, and financial resources are allocated efficiently and that the right policies are adopted and carried out. The most salient ingredient of these policies is introducing real-not cosmetic-public sector reforms and promoting private sector development. This requires better governance and strong institutional capacity based on the rule of law, property rights protection, combating corruption, and broader participation of civil society organizations.

The reasons lying behind the halfhearted efforts to move forward are multifaceted, the most important of which is 


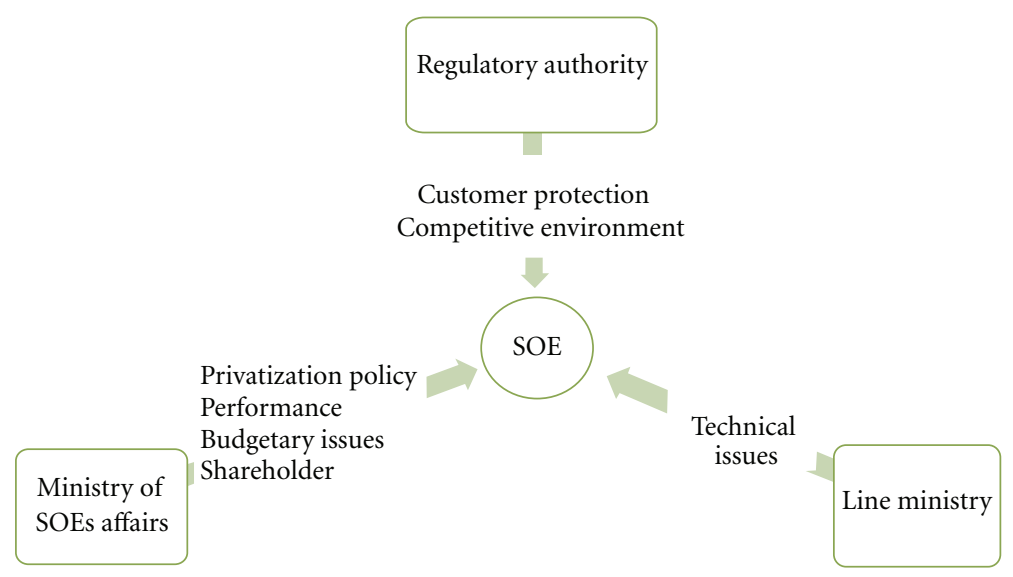

FIGURE 6: State-owned enterprises governance framework.

the lack of genuine political commitment towards genuine reform and the lack of effective institutional arrangements conducive to such reform. This is primarily a result of what is called "state capture," whereby the status quo is protected by those in power and who themselves set the laws and regulations. Hence, reform measures in the region are adopted and implemented, to some extent, via a stop-andgo approach merely to comply with the conditionality of the IMF and the World Bank adjustment programs or to meet the commitments negotiated as part of the accession process to the World Trade Organization.

The solution for the region's economic woes goes way beyond the realm of economics. The lack of political and institutional reforms cast a heavy shadow on its economic future, and without profound progress on this front no tangible socioeconomic benefits are to be anticipated engendering more social unrest.

\section{Policy Recommendations}

The policy options to deal with SOEs may come under three categories: either fold them back into ministries of custody, privatize them, or apply sound corporate governance practices. In any case, the first option is not a viable one for the reasons discussed earlier. The other two policy options are sensible approaches as long as objective examination is undertaken in this regard away from political ideology and dogmatic beliefs. In other words, the choice of a policy option ought to depend on the particular country circumstances, and even in individual countries, the selection of the appropriate policy option ought to be predicated on a close examination of the industry and the SOE in question. A one-size-fits-all approach is not likely to be an effective remedy for state ownership deficiencies.

In case of opting not to privatize, the governance framework proposed in Figure 6 calls for subjecting SOEs to collaboration with and compliance to supervision and regulation of more than one government entity with varying mandates, as opposed to only one ministry of custody. This should help reduce the pressure on SOEs to heed to political pressure. For instance, the industry regulator would play an important role in ensuring a level playing field in the industry, while a line ministry would be the focal point for coordinating government policy with regard to technical issues and overall policy for that particular industry. The Ministry of SOEs Affairs, on its part, would be the shareholder in various SOEs on behalf of the government and would be in charge of privatization policy and monitoring performance of state asset ownership. Thus, the paper offers a policy framework to enhance SOEs performance, in case privatization does not seem as a viable option.

\section{References}

[1] D. Dawley and J. I. Haidar, "Privatization and financial performance: can value be created by privatizing state owned enterprises in the Middle East \& North Africa (MENA) Region?” Journal of Business Valuation and Economic Loss Analysis, vol. 3, no. 1, article 1, 2008.

[2] T. Younis, "Privatization: a review of policy and implementation in selected Arab countries," International Journal of Public Sector Management, vol. 9, no. 3, pp. 18-25, 1996.

[3] S. Haddad and S. Pogodda, "The political economy of governance in the Euro-Mediterranean Partnership," 2006, http://www.go-euromed.org/documents/working_paper/GoEuroMed_WP_0616_UK_Negotiations.pdf.

[4] OECD, Policy Brief on Improving Corporate Governance of Banks in the Middle East and North Africa, 2009.

[5] J. Sullivan and A. Nadgrodkiewicz, "Middle East and North Africa Reform," Economic Reform Issue Paper No. 0804, CIPE, Washington, DC, USA, 2008.

[6] World Bank, Better Governance for Development in the Middle East and North Africa: Enhancing Inclusiveness and Accountability, World Bank, Washington, DC, USA, 2003.

[7] W. Chavanasporn and C. O. Ewald, "Privatization of businesses and flexible investment: a real option approach," Decisions in Economics and Finance, pp. 1-15, 2011.

[8] S. Hertog, "Defying the resource curse: explaining successful state-owned enterprises in rentier states," World Politics, vol. 62, no. 2, pp. 261-301, 2010.

[9] I. Denisova et al., "Everyone hates privatization, but why? Survey evidence from 28 post-communist countries," Journal of Comparative Economics, vol. 40, pp. 44-61, 2012. 
[10] N. Boubakri et al., "The political economy of residual state ownership in privatized firms: evidence from emerging markets," 2009, http://www.fma.org/Singapore/Papers/ThePoliticalEconomyofResidualStateOwnershipinPrivatizedFirms .pdf.

[11] N. Birdsall and J. Nellis, "Winners and losers: assessing the distributional impact of privatization," World Development, vol. 31, no. 10, pp. 1617-1633, 2003.

[12] World Bank, "Bureaucrats in Business," 1995, http://web.worldbank.org/servlets/ECR?entityID=000009265 $3970716145144 \&$ collection $=$ IMAGEBANK\&sitePK $=564626$.

[13] W. L. Megginson and J. M. Netter, "From state to market: a survey of empirical studies on privatization," Journal of Economic Literature, vol. 39, no. 2, pp. 321-389, 2001.

[14] C. Sprenger, "The choice of ownership structure: evidence from Russian mass privatization," Journal of Comparative Economics, vol. 39, no. 2, pp. 260-277, 2011.

[15] K. Crane, "Iraq's jobs-for-peace mirage," 2007, http://www .project-syndicate.org/commentary/crane1/English.

[16] A. Graycar and D. Villa, "The Loss of Governance Capacity through Corruption," Governance, vol. 24, no. 3, pp. 419-438, 2011.

[17] M. Omran, "Performance consequences of privatizing Egyptian state-owned enterprises: the effect of post-privatization ownership structure on firm Performance," Multinational Finance Journal, vol. 8, no. (1-2), p. 73114, 2004.

[18] C. Kauffmann and L. Wegner, "Privatization in the MEDA region," Working Paper no. 261, Development centre, OECD, 2007.

[19] S. Wong, "Improving corporate governance in SOEs: an integrated approach," Corporate Governance International, vol. 7, no. 2, 2004

[20] M. Omran, "Post-privatization corporate governance and Firm performance: the role of private Ownership concentration, identity and board Composition," ERF Working Paper 495, 2009.

[21] J. E. Stiglitz, "Democratizing the international monetary fund and the World Bank: governance and accountability," Governance, vol. 16, no. 1, pp. 111-139, 2003.

[22] K. Reddy, S. Locke, and F. Scrimgeour, "Improving performance in New Zealand's Public Corporations: the effect of governance practices," Governance, vol. 24, no. 3, pp. 517-556, 2011.

[23] K. Shehadi, "Lessons in privatization: considerations for Arab states," 2002, http://www.mafhoum.com/press3/99E16.pdf

[24] OECD, "Ownership structures in MENA countries: listed companies, state-owned, family enterprises and some policy implications," 2005, http://www.oecd.org/dataoecd/26/2/ 35402110.pdf.

[25] Reuters, "Libya aims to privatise half of economy in decade," 2010, http://af.reuters.com/article/newsOne/ idAFJOE62U0EF20100331.

[26] S. Kikeri and A. Kolo, "Privatization: trends and recent developments," Policy Research Working Paper WPS, 3765, World Bank, 2005.

[27] Y. Aharoni, The Evolution and Management of State Owned Enterprises, Ballinger, Cambridge, Mass, USA, 1986.

[28] L. D. Alessi, "Implications of property rights for government investment choices," American Economic Review, vol. 59, no. 1, pp. 13-24, 1969.

[29] A. Ficici, "Political economy of Turkish privatization: a critical assessment," 2001, http://cevdetkizil.com/cevdetkizil/tr/ admin/editor/ccv/genel/poleconomy.pdf.
[30] A. Eberhard and S. Grove, "Improving the performance of SA's state-owned utilities," 2010, http://www.businessday.co.za/ Articles/Content.aspx?id=107596.

[31] B. Bortolotti, "The political economy of privatization: evidence from OECD countries," 2005, http://www bernardobortolotti.com/Userfiles/attach/20107281556574The \%20Political\%20Economy\%20of\%20Privatization.pdf.

[32] A. Belke et al., "The different extent of privatization proceeds in EU countries: a preliminary explanation using a public choice approach," Universitat Hohenheim Nr. 264/2005, 2005.

[33] S. Fink, "A contagious concept: explaining the spread of privatization in the telecommunications sector," Governance, vol. 24, no. 1, pp. 111-139, 2011.

[34] H. Obinger and R. Zohlnhofer, "Selling off the "Family Silver": the politics of privatization in the OECD 1990-2000," Working Paper No. 121, Center for European Studies, Harvard University, 2004.

[35] Eurodad, "World Bank and IMF conditionality: a development injustice," 2006, http://www.eurodad.org/uploadedFiles/ Whats_New/Reports/Eurodad_World_Bank_and_IMF_Conditionality_Report.pdf.

[36] J. Beinin, "Popular social movements and the future of Egyptian politics," 2005, http://www.merip.org/mero/ mero031005.html.

[37] M. Khattab, Privatization in Egypt: Constraints and Resolutions, in Partners for Development, World Bank, 1999.

[38] D. Madzikanda and E. I. Njoku, "Employee attitude towards the privatization of Kuwait's government departments and state Owned enterprises," International Public Management Review, vol. 9, no. 1, 2008.

[39] FWCUI, “Joint statement by leaders of Iraq's labor movement and U.S. labor against the war," 2005, http://fwcui.org/english/ 188.htm

[40] J. Page, "Structural reforms in the Middle East and North Africa," 2003, http://zunia.org/uploads/media/knowledge/1.5_ Structural_Reforms.pdf.

[41] S. Ghazouani, "The impact of corporate governance, ownership structure, and economic and financial liberalization on the financial and operating performance of newly privatized firms in selected MENA countries," 2005, http://www.femise .org/PDF/ao22/FEM2238.pdf.

[42] K. Shehadi, "Video interview," 2009, http://wn.com/WTPF_ 2009_Interview_with_Dr_Kamal_SHEHADI.

[43] J. Choucair, Lebanon: finding a path From deadlock to democracy, Carnegie Papers, Middle East Series. No. 64, 2006.

[44] Financial Times, "Politics clouds state sell-offs in Lebanon," 2010, http://www.ft.com/cms/s/0/41471572-8b43-11de-9f5000144feabdc0.html.

[45] S. Berg, L. Jiang, and C. Lin, "Regulation and corporate corruption: new evidence from the telecom sector," Journal of Comparative Economics, vol. 40, pp. 22-43, 2012. 


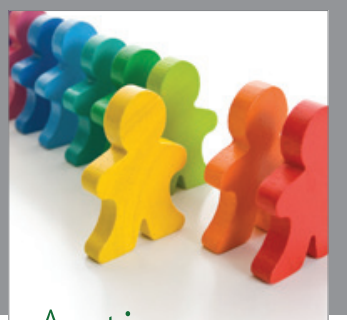

Autism

Research and Treatment
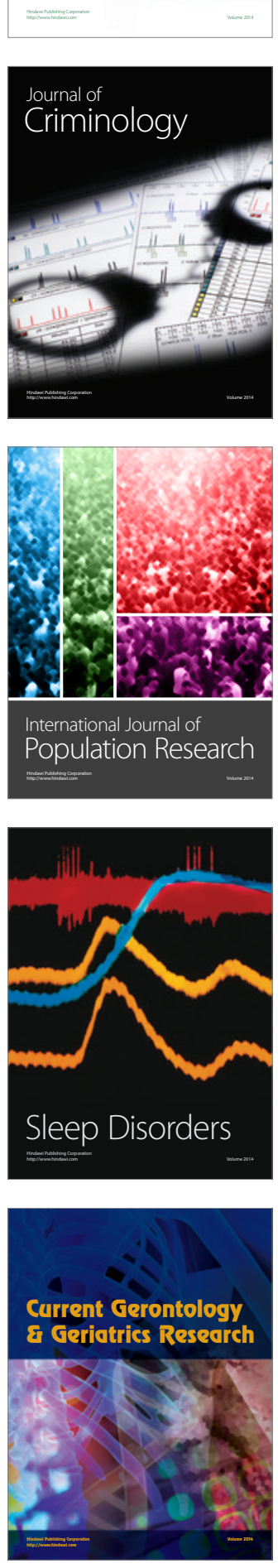
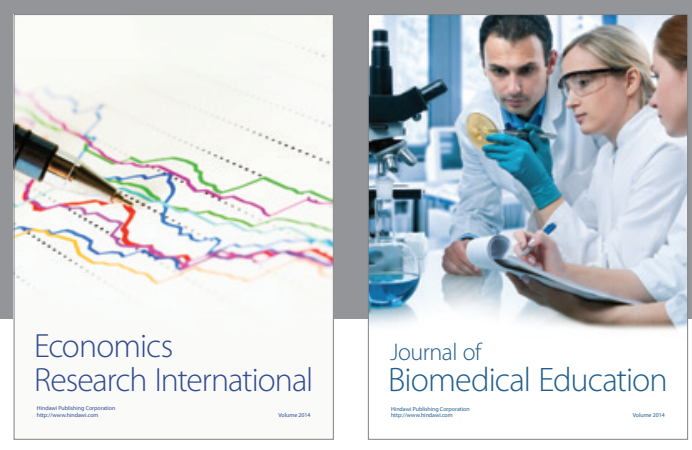

Journal of

Biomedical Education

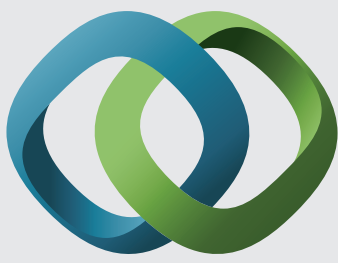

\section{Hindawi}

Submit your manuscripts at

http://www.hindawi.com
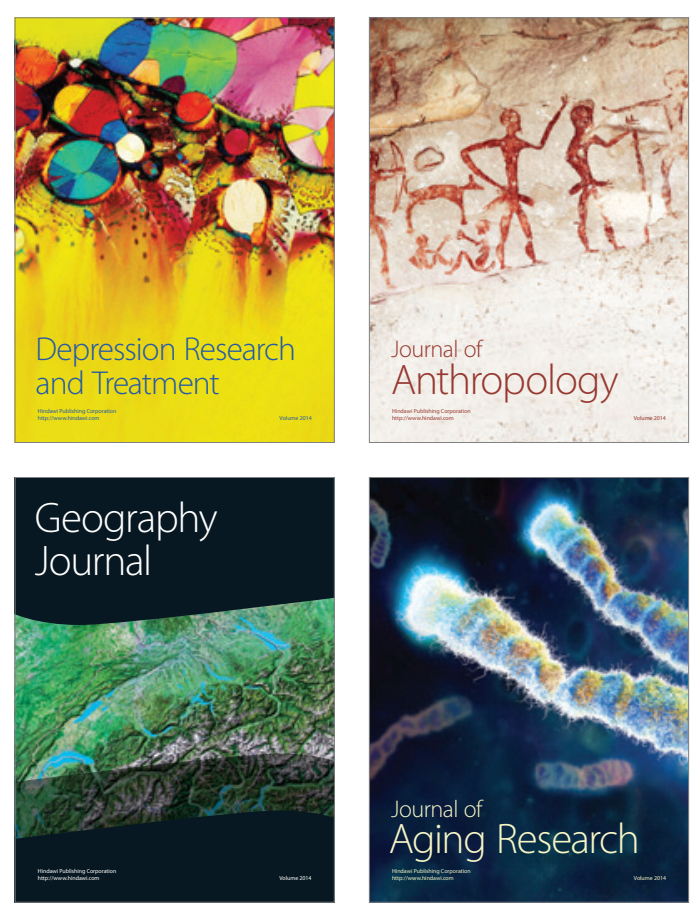

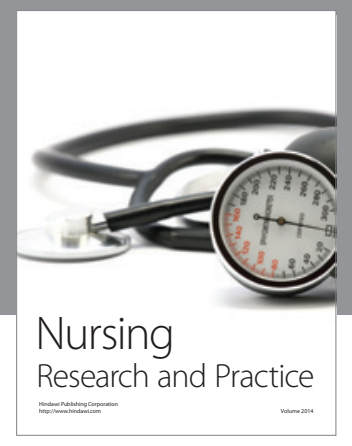

Nursing

Research and Practice

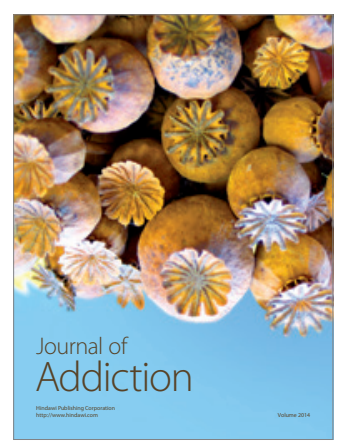

Child Development

Research

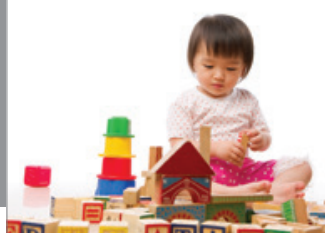

迥
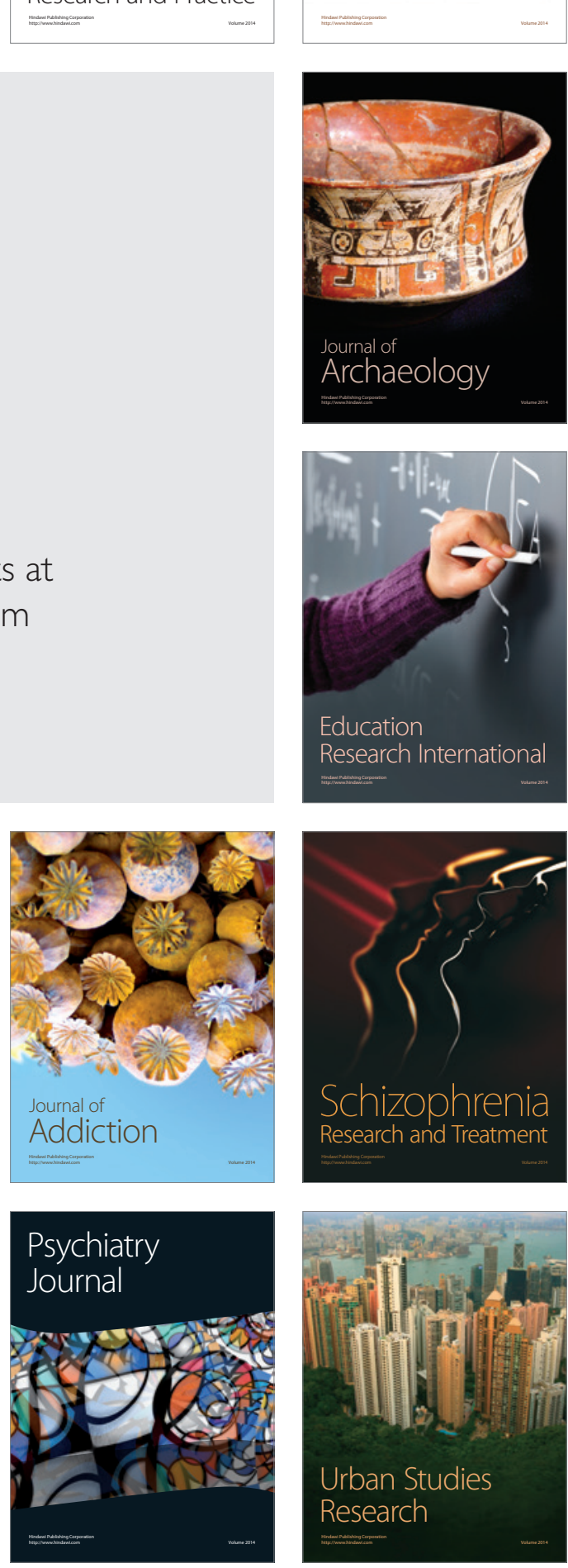